\title{
Cationic and anionic energetic materials based on a new amphotère
}

\author{
Yuangang $\mathrm{Xu}^{1}$, Pengcheng Wang ${ }^{1}$, Qiuhan $\mathrm{Lin}^{1}$, Yao $\mathrm{Du}^{2}$ and Ming $\mathrm{Lu}^{1 *}$
}

In general, amphotères can be divided into organic and inorganic amphoteric compounds. Oxides and hydroxides of aluminum, gallium, zinc, copper and chromium are inorganic amphoteric compounds [1], while organic amphoteric compounds, such as amino acids, peptides and proteins, usually include amino and carboxyl groups in one molecule [2]. In the field of energetic materials, some significant progresses have been made in recent years; however, amphoteric molecules are relatively rare [3-8]. As shown in Scheme 1, 1H-tetrazole (TZ) is an important core of energetic materials because of its practical significance and diversity of properties. TZ can be deprotonated to an anionic TZ-b easily using common bases such as hydrazine, ammonia, or alkali and alkaline earth metal hydroxides or carbonates $[9,10]$. It can also be protonated to a cationic TZ-a under perchloric acid, but it is relatively difficult [11]. Similar to TZ, 5-aminotetrazole (5-ATZ), a weak acid $\left(\mathrm{pK}_{\mathrm{a}} \sim 6\right)$, nitrogen-rich (82\%) compound, also presents an amphoteric characteristic and undergoes two acid-base equilibria, leading to three distinct states (neutral, cationic 5-ATZ-a, and anionic 5ATZ-b), as depicted in Scheme 1 [12-14]. But it has most

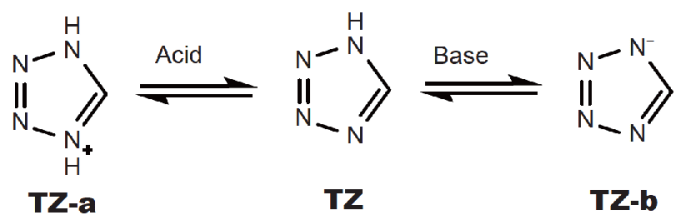<smiles></smiles>

5-ATZ-a<smiles>N[C+](N)C([N+](=O)[O-])[N+](=O)[O-]</smiles>

FOX-7-a<smiles>NN[C+](N)C([N+](=O)[O-])([N+](=O)[O-])[N+](=O)[O-]</smiles>

HFOX-a

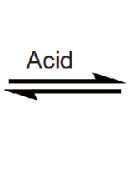

5-ATZ<smiles>Nc1nnn[nH]1</smiles><smiles>C=C</smiles><smiles>Nc1nnn[nH]1</smiles>

5-ATZ-b

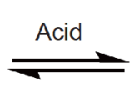<smiles>NC(N)=C([N+](=O)[O-])[N+](=O)[O-]</smiles>

FOX-7

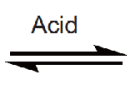

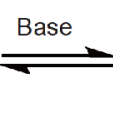

Base<smiles>NNC(N)=C([N+](=O)[O-])[N+](=O)[O-]</smiles>

HFOX<smiles>N=C(N)C([N+](=O)[O-])[N+](=O)[O-]</smiles>

FOX-7-b<smiles>N/N=C(\N)C(N=O)([N+](=O)[O-])[N+](=O)[O-]</smiles>

HFOX-b

Scheme 1 Different distinct states of TZ, 5-ATZ, FOX-7, and HFOX.

${ }^{1}$ School of Chemical Engineering, Nanjing University of Science and Technology, Nanjing 210094, China

${ }^{2}$ School of Materials Science \& Engineering, Beijing Institute of Technology, Beijing 100081, China

* Corresponding author (email: luming@njust.edu.cn) 
<smiles>O=[N+]([O-])Nc1nc[nH]n1</smiles>

A<smiles>O=[N+]([O-])Nc1nc([N+](=O)[O-])nn1CCn1nc([N+](=O)[O-])nc1N[N+](=O)[O-]</smiles>

$\mathbf{F}$<smiles>O=[N+]([O-])Nn1ccnn1</smiles>

C<smiles>O=[N+]([O-])Nn1nc([N+](=O)[O-])nc1-c1nc([N+](=O)[O-])nn1N[N+](=O)[O-]</smiles>

D<smiles>O=[N+]([O-])Nc1nc([N+](=O)[O-])nn1C([N+](=O)[O-])([N+](=O)[O-])[N+](=O)[O-]</smiles>

E<smiles></smiles>

G

Figure 1 Energetic derivatives of triazole. 3-nitroamino-1,2,4-triazole (A), 4-nitroamino-1,2,4-triazole (B), 1-nitroamino-1,2,3-triazole (C), $N, N^{\prime}$ (5,5'-dinitro-2H,2'H-3,3'-bi(1,2,4-triazole)-2,2'-diyl)dinitramide (D), $N$-(3-nitro-1-(trinitromethyl)-1H-1,2,4-triazol-5-yl)nitramide (E), $N, N^{\prime}$-(1,1'(ethane-1,2-diyl)bis(3-nitro-1H-1,2,4-triazole-5,1-diyl))dinitramide (F), and bis[3-(5-nitroamino-1,2,4-triazole)] (G).

often been employed as a cation precursor in energetic salts $[15,16]$. In addition to TZ and 5-ATZ, 1,1-diamino2,2-dinitroethene (FOX-7) and 1-amino-1-hydrazino-2,2dinitroethene (HFOX) also exhibit amphoteric properties (Scheme 1) [17-21].

Triazole derivatives have been used successfully to produce a large number of energetic materials. Nitroamino-substituted monocyclic and bridged bicyclic triazoles are very important species (Fig. 1 A-G) [22-27]. By implementing nitroamino moieties, the oxygen balance and the energetic performance of the target molecule can be optimized. Simultaneously, the chemistry of A-G with bases to generate the corresponding anionic substrates was well established. But they have never been employed as cation precursors in energetic salts. 5,5'diamino-4,4'-dinitramino-3,3'-bi-1,2,4-triazole (1) and its anionic salts based on 1-b were synthesized by Klapötke et al. [28-30] in 2016. However, evidence for protonated 1 was not developed. The isolation of such species is of great interest to study a new form of nitroamino- and amino-substituted triazole and these molecules have potential as promising precursors that may enhance the properties of energetic salts. Herein we describe protonated $\mathbf{1}$ and coordination of $\mathbf{1 - b}$ by the syntheses of salt containing the first cationic state of $\mathbf{1}$ and the potassium based 3D metal-organic framework (MOF) of 1-b.

For the protonated products of $\mathbf{1}$, there are four possible forms (1-a1-1-a4, see Scheme 2). Theoretically, except for the two nitroamino groups and the nitrogen atoms to which they are attached, other nitrogen atoms may be protonated with acids. Single-crystal X-ray analysis indicated that the proton was introduced at the $\mathrm{N} 2$ nitrogen and double bond transferred from C-N2 to C$\mathrm{N} 3$, leading to the formation of 1-a4.

Compound 1 can be obtained by selective nitration of 4,4',5,5'-tetraamino-3,3'-bi-1,2,4-triazole (2) or a new synthetic route from 3,9-diamino-6,7-dihydro-5H-bis $([1,2,4]$ triazolo $)\left[4,3-e: 3^{\prime}, 4^{\prime}-g\right][1,2,4,5]$ tetrazepine-2,10diium chloride (3) [31,32]. Deprotonation of $\mathbf{1}$ with $\mathrm{KOH}$ gave the dipotassium salt 4 . Compound $\mathbf{1}$ was first treated with an excess of nitric acid $\left(\mathrm{HNO}_{3}\right)$ at $25^{\circ} \mathrm{C}$ to yield nitrate monohydrate (crystals), 5 (Scheme 3).

Compound 1 (Fig. S1) crystallizes in the orthorhombic space group $\mathrm{Pbca}$ with four molecules in the unit cell with a calculated density of $1.783 \mathrm{~g} \mathrm{~cm}^{-3}$ at $205 \mathrm{~K}\left(1.789 \mathrm{~g} \mathrm{~cm}^{-3}\right.$ at $173 \mathrm{~K}$ [28]). 1 has a zwitterionic resonance structure with a formal negative charge at the nitrogen atom N2 and a protonated nitrogen atom N5. A very strong intermolecular hydrogen bond is found between the atoms N5

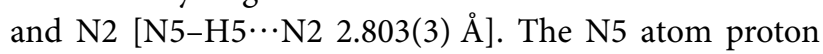
forms two weak hydrogen bonds to the nitro group [N5-

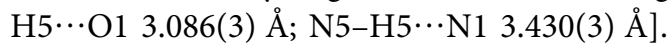

Suitable single crystals of $\mathbf{4}$ were grown in water solutions. Complex 4 crystallizes as a dihydrate in the monoclinic space group with a 3D porous framework. As depicted in Fig. 2, the central $\mathrm{K}$ ion displays a distorted quadrangular pyramid coordinated by three nitrogen atoms (N3, N6, and N6) from three different 1-b ligands and two oxygen atoms (O3) from water molecules. Each 1-b ligand exhibits a tetradentate coordination mode (see Fig. 2a), in which the N3 and N6 atoms adopt a bridging mode to connect to six different $\mathrm{K}$ ions. Every two adjacent amino groups (N6) of different ligands are bridged by two $\mathrm{K}$ ions to form a $1 \mathrm{D}$ chain. A $2 \mathrm{D}$ layer is formed 
<smiles></smiles><smiles>Nc1nnc(-c2nnc(N)n2N[N+](=O)[O-])n1N[N+](=O)[O-]</smiles><smiles></smiles><smiles>Nc1[nH+]nc(-c2n[nH+]c(N)n2NN=O)n1NN=O</smiles><smiles>[NH3+]c1nnc(-c2nnc([NH3+])n2N[N+](=O)[O-])n1N[N+](=O)[O-]</smiles>

1-a3<smiles>[NH2+]=c1[nH]nc(-c2n[nH]c(=[NH2+])n2N[N+](=O)[O-])n1NNO</smiles>

Scheme 2 Possible deprotonation and protonation sites of $\mathbf{1 .}$<smiles>CO[C@H](C)[C@H](C)O</smiles>

2<smiles></smiles>

3

$100 \% \mathrm{HNO}_{3}$ $-5^{\circ} \mathrm{C}, 1.5 \mathrm{~h}$

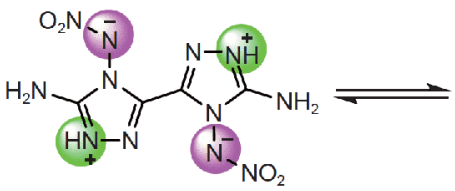

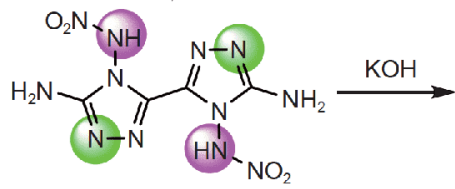

1<smiles>[Y][CH]Nn1c(N)nnc1-c1nnc(N)n1[N-][N+](=O)[O-]</smiles><smiles>[NH2+][NH+]([O-])O[N+](=O)[O-]</smiles>

5

Scheme 3 Synthesis of 1, 4 and 5.

based on the coordination of N3 atoms with $\mathrm{K}$ ions (N3K: $3.1024 \AA$ ) in the direction of $a$ axis (Fig. 2c). The adjacent layers are linked by coordination of $\mathrm{O} 3$ from $\mathrm{H}_{2} \mathrm{O}$ molecules with $\mathrm{K}$ ions (O3-K: 3.2129 and $3.2295 \AA$ ), producing the stable 3D supramolecular network (see Fig. $2 \mathrm{~d}$ ). In terms of topology, the ligand can be viewed as an ensemble of eight-connected (8-c) node, with the $\mathrm{K}^{+}$ serving as six-connected (6-c) node. Thus, the underlying binodal $(6,8-c)$ net with stoichiometry $(6-c)_{2}(8-c)$ presents a new topology (see Fig. S4).

Salt 5 crystallizes with one molecule of water in the monoclinic space group $P 12_{1} / c 1$ system (Fig. 3). It is composed of four molecules per unit cell with a crystal density of $1.878 \mathrm{~g} \mathrm{~cm}^{-3}$ at $173 \mathrm{~K} .5$ has two protonated nitrogen atoms ( $\mathrm{N} 6$ and $\mathrm{N} 3$ ) in the triazole moieties and two protonated nitrogen atoms ( $\mathrm{N} 9$ and $\mathrm{N} 11)$ in the 


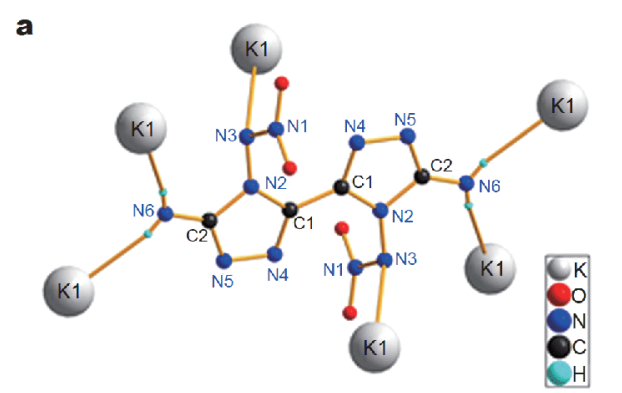

b
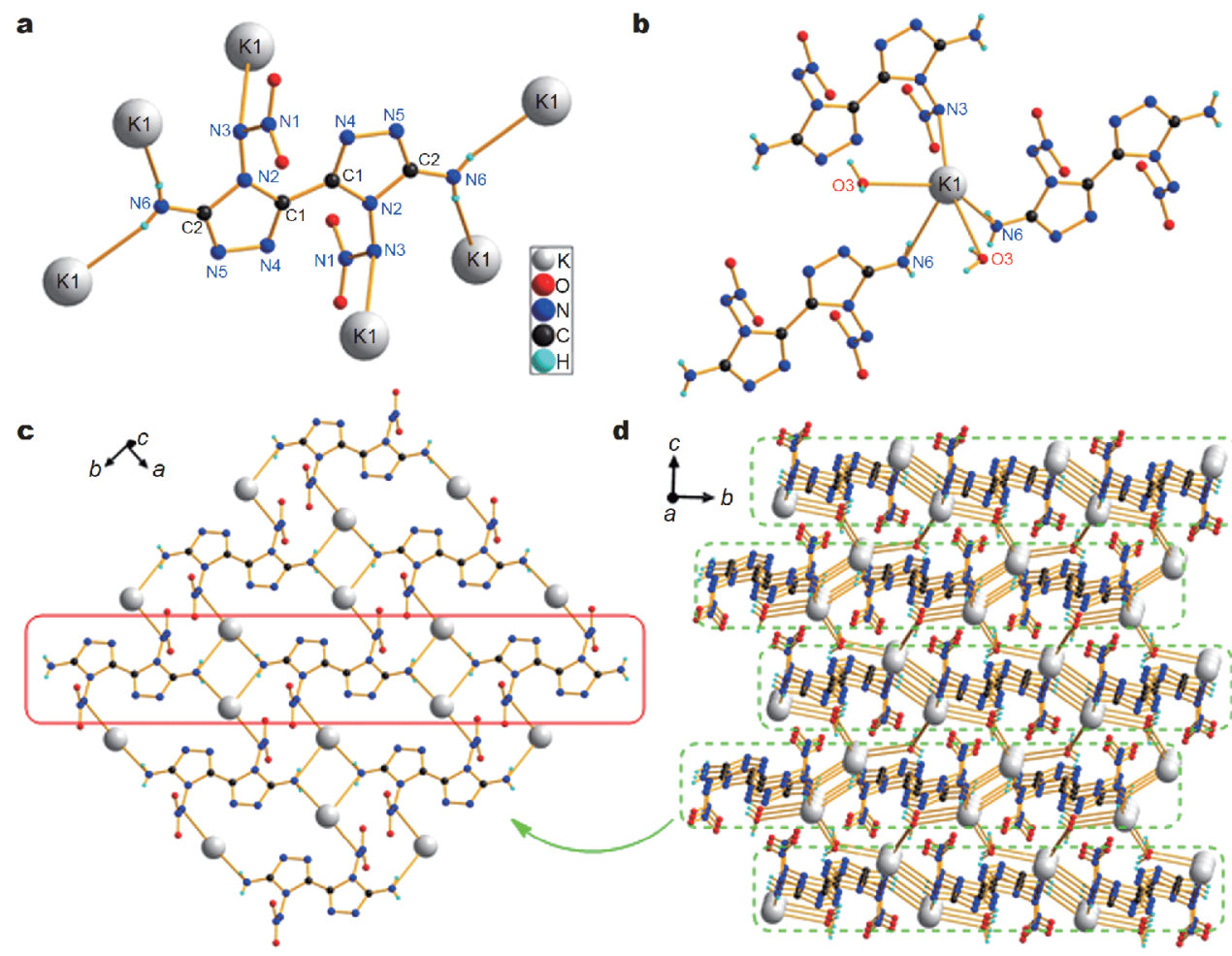

d

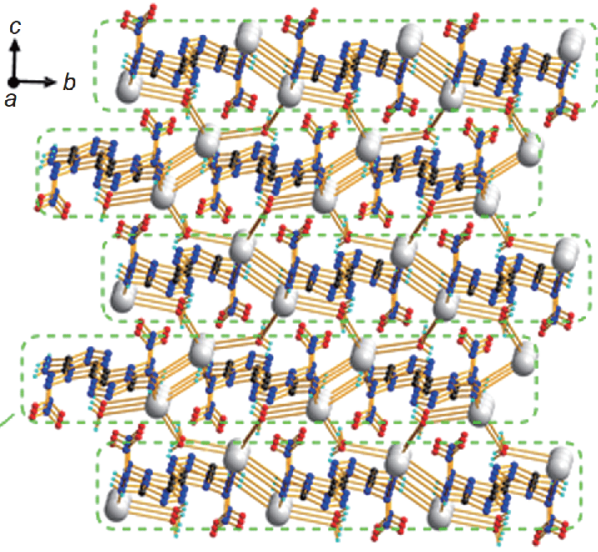

Figure 2 (a) Coordination model of $\mathbf{1 - b}$ in $\mathbf{4} \cdot 2 \mathrm{H}_{2} \mathrm{O}$. (b) Coordination environment of $\mathrm{K}^{+}$in $\mathbf{4} \cdot 2 \mathrm{H}_{2} \mathrm{O}$. (c) The $2 \mathrm{D}$ layer in $\mathbf{4} \cdot 2 \mathrm{H}_{2} \mathrm{O}$. (d) The $3 \mathrm{D}$ supramolecular framework in $\mathbf{4} \cdot 2 \mathrm{H}_{2} \mathrm{O}$ viewed down $a$ axis.
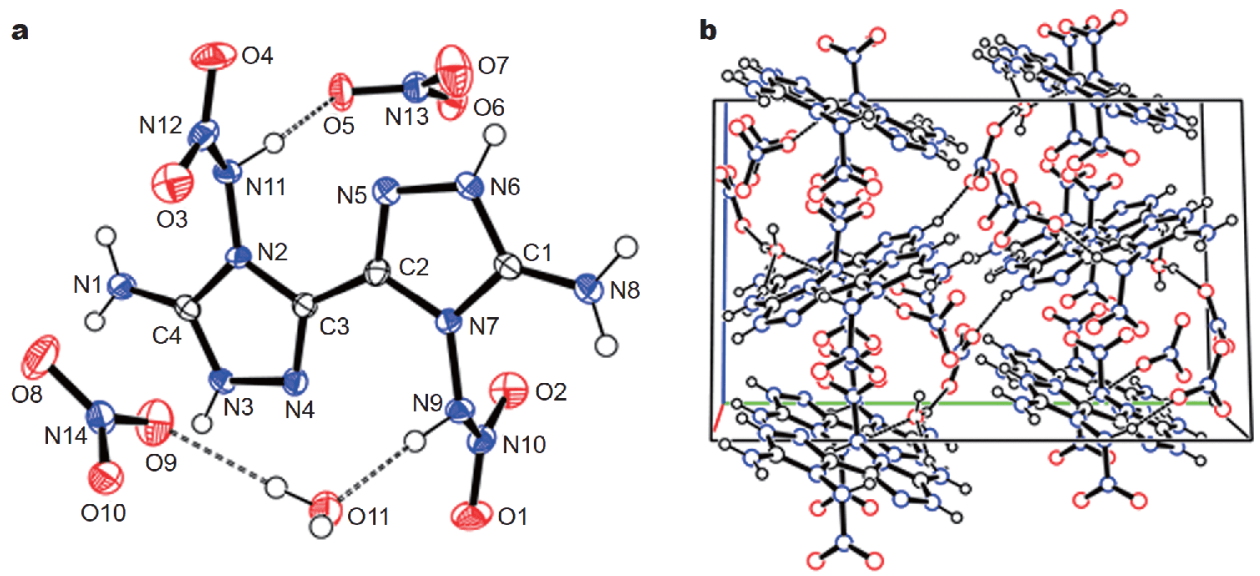

Figure 3 (a) Crystal structure of $\mathbf{5}$; thermal ellipsoids are drawn at the 50\% probability level. (b) Packing diagram of $\mathbf{5}$ viewed down the $a$ axis. Unit cell indicated and dashed lines represent hydrogen bonding.

nitramino moieties. To obtain a better understanding of interactions between 1-a4 and nitrate ions, the twodimensional (2D) fingerprint plot of 1-a4 in the crystal stacking of $\mathbf{5}$ and the associated Hirshfeld surface were calculated [33] (see Fig. 4). Only one remarkable spike on the bottom left $(\mathrm{H} \cdots \mathrm{O}$ interactions constitute $31.2 \%$ of the total weak interactions) in the Fig. 4 a denotes the hydrogen bonds (blue dashed lines in Fig. 4b) from 1-a4 to nitrate ions and water molecules, while weaker $\mathrm{O} \cdots \mathrm{O}$, $\mathrm{O} \cdots \mathrm{N}$, and $\mathrm{O} \cdots \mathrm{C}$ interactions were found among neighboring 1-a4 cations.

By comparison, we specify the atomic labels of 1, 1-b in 4. $2 \mathrm{H}_{2} \mathrm{O}$, and 1-a4 in $\mathbf{5}$ as shown in Table 1. The C1-C1' and the $\mathrm{C} 2-\mathrm{N} 4$ bonds in 1-a4 are shorter than those in $\mathbf{1}$ 
a

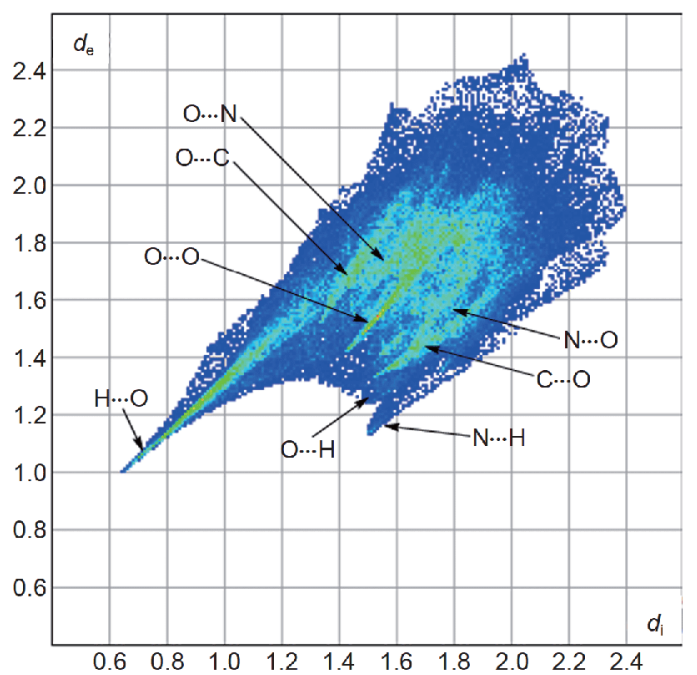

b

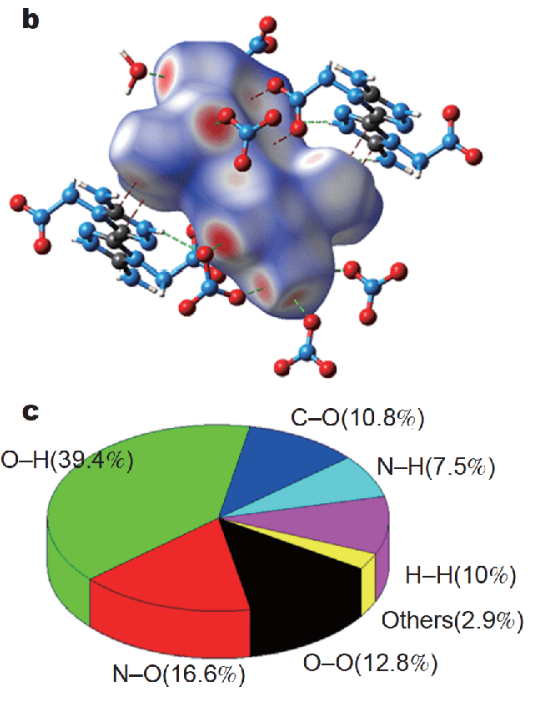

Figure 4 (a) 2D fingerprint plot of 1-a4 in the crystal stacking of 5. (b) Hirshfeld surface for 1-a4. (c) The individual atomic contact percentage contribution to the Hirshfeld surface.

Table 1 Selected bond lengths $(\AA)$, angles $\left({ }^{\circ}\right)$ and torsion angles $\left(^{\circ}\right)$ of 1, 1-b in $\mathbf{4} \cdot 2 \mathrm{H}_{2} \mathrm{O}$, and $\mathbf{1 - a 4}$ in $\mathbf{5}$

\begin{tabular}{|c|c|c|c|}
\hline & 1 & $\mathbf{1 - b}$ in $\mathbf{4} \cdot 2 \mathrm{H}_{2} \mathrm{O}$ & $1-\mathrm{a} 4$ in 5 \\
\hline \multicolumn{4}{|l|}{ Bond lengths } \\
\hline $\mathrm{C} 1-\mathrm{C} 1^{\prime}$ & $1.559(4)$ & $1.447(5)$ & $1.443(3)$ \\
\hline $\mathrm{C} 1-\mathrm{N} 1$ & $1.284(3)$ & $1.288(3)$ & $1.288(3)$ \\
\hline $\mathrm{C} 2-\mathrm{N} 2$ & $1.405(3)$ & $1.332(3)$ & $1.335(3)$ \\
\hline $\mathrm{C} 1-\mathrm{N} 3$ & $1.359(3)$ & $1.392(3)$ & $1.388(3)$ \\
\hline $\mathrm{C} 2-\mathrm{N} 3$ & $1.405(3)$ & $1.367(3)$ & $1.365(3)$ \\
\hline $\mathrm{C} 2-\mathrm{N} 4$ & $1.459(3)$ & $1.299(3)$ & $1.301(3)$ \\
\hline $\mathrm{N} 1-\mathrm{N} 2$ & $1.527(3)$ & $1.378(3)$ & $1.378(3)$ \\
\hline N3-N5 & $1.384(2)$ & $1.370(3)$ & $1.368(3)$ \\
\hline N5-N6 & $1.235(2)$ & $1.427(3)$ & $1.417(3)$ \\
\hline \multicolumn{4}{|l|}{ Bond angles } \\
\hline N6-N5-N3 & $101.72(16)$ & $113.66(19)$ & $112.94(17)$ \\
\hline \multicolumn{4}{|l|}{ Torsion angles } \\
\hline $\mathrm{N} 3-\mathrm{C} 1-\mathrm{C} 1^{\prime}-\mathrm{N} 3^{\prime}$ & 180.00 & 180.00 & 179.50 \\
\hline $\mathrm{N} 1-\mathrm{N} 2-\mathrm{C} 2-\mathrm{N} 4$ & 178.60 & 178.65 & 178.60 \\
\hline
\end{tabular}

and similar to those in 1-b. The observed bond lengths of $\mathrm{N} 3-\mathrm{N} 5$ and N5-N6 in the three compounds are between the values of a $\mathrm{N}-\mathrm{N}$ single bond and a $\mathrm{N}=\mathrm{N}$ double bond due to electron delocalization in the triazole ring. The $\mathrm{N} 3-\mathrm{C} 1-\mathrm{Cl}^{\prime}-\mathrm{N} 3$ and $\mathrm{N} 1-\mathrm{N} 2-\mathrm{C} 2-\mathrm{N} 4$ torsion angles are nearly $180^{\circ}$, which means both ring systems and the amino groups are located in plane. The two nitramino groups are tilted out of the plane by $78^{\circ}(\mathbf{1}), 66^{\circ}(\mathbf{1}-\mathbf{b})$, and $67^{\circ}$ (1-a4), respectively.

The physiochemical energetic properties for 1, 4, 5 and standard energetic properties for comparison are reported in Table 2. The thermal stability (onset temperature) of $\mathbf{4}$ and 5 were evaluated by thermal gravimetric analysis (TGA, see Fig. S5). 4 has good thermal stability with an onset decomposition temperature $\left(T_{\mathrm{dec}}\right)$ of $220.4^{\circ} \mathrm{C}$, which is comparable to that of the reported potassium based primary explosives, such as potassium $4,4^{\prime}$-bis(dinitromethyl)3,3'-azofurazanate $\left(229^{\circ} \mathrm{C}\right)$ [34] and potassium 4,5-bis (dinitromethyl)furoxanate $\left(218^{\circ} \mathrm{C}\right)$ [35], and slightly lower than that of the dilithium 3,3'-diamino-4,4'dinitramino-5, $5^{\prime}$-bi-1,2,4-triazolate trihydrate $\left(240^{\circ} \mathrm{C}\right)$ [29]. The weight loss $(4.3 \%)$ at $108.3^{\circ} \mathrm{C}$ for protonated compound $\mathbf{5}$ was related to dehydration; however it was found to be more thermally stable $\left(T_{\mathrm{dec}}=262.2^{\circ} \mathrm{C}\right)$ than deprotonated product 4 , while they have better thermal stabilities than RDX (1,3,5-trinitro-1,3,5-triazacyclohexane, $204^{\circ} \mathrm{C}$ ).

Experimental densities measured at $25^{\circ} \mathrm{C}$ show that the protonated compound $\mathbf{5}$ has a higher density $\left(1.84 \mathrm{~g} \mathrm{~cm}^{-3}\right)$ than RDX and 1 . The density of $\mathbf{4}$ is $1.98 \mathrm{~g} \mathrm{~cm}^{-3}$ and it is equal to that of the potassium based 3D MOF, potassium 4-(5-amino-3-nitro-1H-1,2,4-triazol -1-yl)-3,5-dinitropyrazole [36]. 
Table 2 Physiochemical properties and energetic performances of $\mathbf{1 , 4} \mathbf{4}$, and comparison with traditional energetic materials

\begin{tabular}{|c|c|c|c|c|c|}
\hline & $1^{a}$ & 4 & $\mathrm{~Pb}\left(\mathrm{~N}_{3}\right)_{2}$ & 5 & RDX \\
\hline$\rho^{\mathrm{b}}\left(\mathrm{g} \mathrm{cm}^{-3}\right)$ & $1.76 / 1.78$ & 1.98 & 4.8 & $1.84 / 1.88$ & 1.8 \\
\hline$T_{\mathrm{dec}}{ }^{\mathrm{c}}\left({ }^{\circ} \mathrm{C}\right)$ & 259 & 220.4 & 315 & 262.2 & 204 \\
\hline $\mathrm{OB}^{\mathrm{d}}(\%)$ & -16.8 & -13.2 & -11.0 & 7.4 & 0.0 \\
\hline$N^{\mathrm{e}}(\%)$ & 58.73 & 46.38 & 28.9 & 45.58 & 37.84 \\
\hline $\mathrm{N}+\mathrm{O}^{\mathrm{f}}(\%)$ & 81.10 & 64.05 & 28.9 & 86.49 & 81.05 \\
\hline$\Delta H_{\mathrm{f}}^{\mathrm{g}}\left(\mathrm{kJ} \mathrm{mol}^{-1}\right)$ & 691.9 & 531.6 & 450.1 & 70.9 & 70.3 \\
\hline$T_{\text {det }}^{\mathrm{h}}(\mathrm{K})$ & 3,771 & 3,451 & 3,353 & 3,747 & 3,810 \\
\hline$D^{\mathrm{i}}\left(\mathrm{m} \mathrm{s}^{-1}\right)$ & 8,846 & 7,827 & 5,877 & 9,076 & 8,795 \\
\hline$P^{\mathrm{j}}(\mathrm{GPa})$ & 31.2 & 25.8 & 33.4 & 35.7 & 34.9 \\
\hline $\mathrm{IS}^{\mathrm{k}}(\mathrm{J})$ & 9 & 4 & $2.5-4$ & 8 & 7.5 \\
\hline $\mathrm{FS}^{1}(\mathrm{~N})$ & 120 & 40 & $0.1-1$ & 200 & 120 \\
\hline
\end{tabular}

a) Ref. [28]. b) Density measured by a gas pycnometer at $25^{\circ} \mathrm{C}$. Values after slashes were crystal densities. c) Decomposition temperature from TGA $\left(5^{\circ} \mathrm{C} \mathrm{min}^{-1}\right)$. d) Oxygen balance (based on CO). e) Nitrogen content. f) Nitrogen and oxygen content. g) Calculated heat of formation in solid state. h) Detonation temperature. i) Calculated detonation velocity. j) Calculated detonation pressure. k) Impact sensitivity. l) Friction sensitivity.

The heats of formation of $\mathbf{4}$ and $\mathbf{5}$ were calculated by using the Gaussian 09 suite of programs [37] (see the Supplementary information). Using the densities and calculated heats of formation, the energetic properties of 4 and 5 were calculated using Explo5 program [38]. 4 was predicted to have a detonation velocity $(D)$ of $7,872 \mathrm{~m} \mathrm{~s}^{-1}$ and detonation pressure $(P)$ of $25.8 \mathrm{GPa}$ which are superior to those of the traditional primary explosives $\mathrm{Pb}\left(\mathrm{N}_{3}\right)_{2}\left(D=5,877 \mathrm{~m} \mathrm{~s}^{-1}, P=33.4 \mathrm{GPa}\right)$. And the detonation temperature of $4(3,451 \mathrm{~K})$ is comparable to that of the $\mathrm{Pb}\left(\mathrm{N}_{3}\right)_{2}(3,353 \mathrm{~K})$. The $D$ of 5 is $9,076 \mathrm{~m} \mathrm{~s}^{-1}$, which is slightly lower than that of HMX (1,3,5,7-tetranitro1,3,5,7-tetraazacyclooctane, $9,221 \mathrm{~m} \mathrm{~s}^{-1}$ ).

The impact and friction sensitivities of $\mathbf{4}$ and $\mathbf{5}$ were determined using a standard BAM fall hammer and a BAM friction tester, respectively [39]. 5 has an acceptable impact sensitivity (IS) of $8 \mathrm{~J}$ and friction sensitivity (FS) of $200 \mathrm{~N}$ compared to those of RDX and HMX (IS = 7.4 J, $\mathrm{FS}=120 \mathrm{~N}$ ). However, it exists as the monohydrate which would lower its measured sensitivities. 4 exhibits sensitivity to external stimuli with an IS of $4 \mathrm{~J}$ and FS of $40 \mathrm{~N}$.

In summary, the exciting discovery of the first isolated cationic 5,5'-diamino-4,4'-dinitramino-3,3'-bi-1,2,4-triazole salt (5) that has been synthesized and fully characterized by single-crystal X-ray analysis. $\mathbf{5}$ is a secondary explosive with high decomposition temperature $\left(262.2^{\circ} \mathrm{C}\right)$, enhanced detonation parameters in comparison to those of RDX, and lower sensitivity to HMX. Coordination of the anionic 5,5'-diamino-4,4'-dinitramino-3,3'-bi-1,2,4-triazole yielded the primary explosive 4 , the higher performance and larger nitrogen and oxygen content of which relative to $\mathrm{Pb}\left(\mathrm{N}_{3}\right)_{2}$ make this compound a competitive candidate as a green primary explosive. The deprotonated and protonated approach resulted in two new compounds which not only fall into different classes of explosives but also show improved or comparable properties to those of the standard compounds.

\section{Received 25 September 2018; accepted 13 November 2018;} published online 22 November 2018

1 Rai D, Eary LE, Zachara JM. Environmental chemistry of chromium. Sci Total Environ, 1989, 86: 15-23

2 Hames D, Hooper N. Biochemistry. New York: Taylor and Francis Group, 2005

3 Singh RP, Verma RD, Meshri DT, et al. Energetic nitrogen-rich salts and ionic liquids. Angew Chem Int Ed, 2006, 45: 3584-3601

4 Gao H, Shreeve JM. Azole-based energetic salts. Chem Rev, 2011, 111: 7377-7436

5 Zhang W, Zhang J, Deng M, et al. A promising high-energydensity material. Nat Commun, 2017, 8: 181

6 Wang Y, Liu Y, Song S, et al. Accelerating the discovery of insensitive high-energy-density materials by a materials genome approach. Nat Commun, 2018, 9: 2444

7 Yan C, Yang H, Qi X, et al. A simple and versatile strategy for taming FOX-7. Chem Commun, 2018, 54: 9333-9336

8 Wang $\mathrm{P}, \mathrm{Xu} \mathrm{Y}$, Lin $\mathrm{Q}$, et al. Recent advances in the syntheses and properties of polynitrogen pentazolate anion $c y c l o-\mathrm{N}_{5}{ }^{-}$and its derivatives. Chem Soc Rev, 2018, 47: 7522-7538

9 Klapötke TM, Stein M, Stierstorfer J. Salts of $1 H$-tetrazolesynthesis, characterization and properties. Z Anorg Allg Chem, 2008, 634: 1711-1723

10 Klapötke TM, Radies H, Stierstorfer J, et al. Coloring properties of various high-nitrogen compounds in pyrotechnic compositions. Prop Explos Pyrotech, 2010, 35: 213-219

11 Klapötke TM, Stierstorfer J. Azidoformamidinium and 5-aminotetrazolium dinitramide-two highly energetic isomers with a balanced oxygen content. Dalton Trans, 2009, 643-653 
12 Ernst V, Klapötke TM, Stierstorfer J. Alkali salts of 5-aminotetrazole-structures and properties. Z Anorg Allg Chem, 2007, 633: 879-887

13 von Denffer M, Klapötke TM, Miró Sabaté C. Hydrates of 5amino- $1 H$-tetrazolium halogenide salts-starting materials for the synthesis of energetic compounds. Z Anorg Allg Chem, 2008, 634: 2575-2582

14 Tao GH, Guo Y, Joo YH, et al. Energetic nitrogen-rich salts and ionic liquids: 5-aminotetrazole (AT) as a weak acid. J Mater Chem, 2008, 18: 5524-5530

15 von Denffer M, Klapötke TM, Kramer G, et al. Improved synthesis and X-ray structure of 5-aminotetrazolium nitrate. Prop Explo Pyrotech, 2005, 30: 191-195

16 Jin CM, Ye C, Piekarski C, et al. Mono and bridged azolium picrates as energetic salts. Eur J Inorg Chem, 2005, 2005: 3760-3767

17 Garg S, Gao H, Joo YH, et al. Taming of the silver FOX. J Am Chem Soc, 2010, 132: 8888-8890

18 Garg S, Gao H, Parrish DA, et al. FOX-7 (1,1-diamino-2,2-dinitroethene): trapped by copper and amines. Inorg Chem, 2011, 50: 390-395

19 Vo TT, Parrish DA, Shreeve JM. 1,1-Diamino-2,2-dintroethene (FOX-7) in copper and nickel diamine complexes and copper FOX-7. Inorg Chem, 2012, 51: 1963-1968

20 Vo TT, Shreeve JM. 1,1-Diamino-2,2-dinitroethene (FOX-7) and 1-amino-1-hydrazino-2,2-dinitroethene (HFOX) as amphotères: bases with strong acids. J Mater Chem A, 2015, 3: 8756-8763

21 Gao H, Shreeve JM. Recent progress in taming FOX-7 (1,1-diamino-2,2-dinitroethene). RSC Adv, 2016, 6: 56271-56277

22 Gao H, Huang Y, Ye C, et al. The synthesis of di(aminoguanidine) 5-nitroiminotetrazolate: some diprotic or monoprotic acids as precursors of energetic salts. Chem Eur J, 2008, 14: 5596-5603

23 Huang Y, Gao H, Twamley B, et al. Nitroamino triazoles: nitrogenrich precursors of stable energetic salts. Eur J Inorg Chem, 2008, 2008: 2560-2568

24 Wang R, Xu H, Guo Y, et al. Bis[3-(5-nitroimino-1,2,4-triazolate)]based energetic salts: synthesis and promising properties of a new family of high-density insensitive materials. J Am Chem Soc, 2010, 132: 11904-11905

25 Yin P, Parrish DA, Shreeve JM. Bis(nitroamino-1,2,4-triazolates): $N$-bridging strategy toward insensitive energetic materials. Angew Chem Int Ed, 2014, 53: 12889-12892

26 Yin P, Shreeve JM. From $N$-nitro to $N$-nitroamino: preparation of high-performance energetic materials by introducing nitrogencontaining ions. Angew Chem Int Ed, 2015, 54: 14513-14517

27 Liu T, Qi X, Wang K, et al. Green primary energetic materials based on $N$-(3-nitro-1-(trinitromethyl)-1H-1,2,4-triazol-5-yl)nitramide. New J Chem, 2017, 41: 9070-9076

28 Klapötke TM, Leroux M, Schmid PC, et al. Energetic materials based on 5,5'-diamino-4,4'-dinitramino-3,3'-bi-1,2,4-triazole. Chem Asian J, 2016, 11: 844-851

29 Glück J, Klapötke TM, Rusan M, et al. A strontium- and chlorinefree pyrotechnic illuminant of high color purity. Angew Chem Int
Ed, 2017, 56: 16507-16509

30 Glück J, Gospodinov I, Klapötke TM, et al. Metal salts of 3,3'diamino-4,4'-dinitramino-5,5'-bi-1,2,4-triazole in pyrotechnic compositions. Z Anorg Allg Chem, 2018, doi: 10.1002/ zaac. 201800179

$31 \mathrm{Xu} \mathrm{Y,} \mathrm{Zhu} \mathrm{Z,} \mathrm{Shen} \mathrm{C,} \mathrm{et} \mathrm{al.} \mathrm{In} \mathrm{situ} \mathrm{synthesized} \mathrm{energetic} \mathrm{salts} \mathrm{based}$ on the $\mathrm{C}-\mathrm{N}$ fused tricyclic 3,9-diamine-6,7-dihydro-bis(triazolo)tetrazepine cation: a family of high-performance energetic materials. Prop Explos Pyrotech, 2018, 43: 595-601

$32 \mathrm{Xu} \mathrm{Y,} \mathrm{Lin} \mathrm{Q,} \mathrm{Wang} \mathrm{P,} \mathrm{et} \mathrm{al.} \mathrm{Stabilization} \mathrm{of} \mathrm{the} \mathrm{pentazolate} \mathrm{anion}$ in three anhydrous and metal-free energetic salts. Chem Asian J, 2018, 13: 924-928

33 Turner MJ, McKinnon JJ, Wolff SK, et al. CrystalExplorer17, University of Western Australia. http://hirshfeldsurface.net, 2017

34 Tang Y, He C, Mitchell LA, et al. Potassium 4,4'-bis(dinitromethyl)-3,3'-azofurazanate: a highly energetic 3D metal-organic framework as a promising primary explosive. Angew Chem Int Ed, 2016, 55: 5565-5567

35 He C, Shreeve JM. Potassium 4,5-bis(dinitromethyl)furoxanate: a green primary explosive with a positive oxygen balance. Angew Chem Int Ed, 2016, 55: 772-775

36 Li C, Zhang M, Chen Q, et al. Three-dimensional metal-organic framework as super heat-resistant explosive: potassium 4-(5-amino-3-nitro-1H-1,2,4-triazol-1-yl)-3,5-dinitropyrazole. Chem Eur J, 2017, 23: 1490-1493

37 Frisch MJ, Trucks GW, Schlegel HB, et al. Gaussian 09, Revision A.02, Gaussian, Inc., Wallingford CT, 2009

38 Sućeska M, EXPLO5, Version 6.01, 2013

39 a) Tests were conducted according to the UN Recommendations on the Transport of Dangerous Goods, Manual of Tests and Criteria, 5th rev. edn, United Nations Publication, New York, 2009. b) 13.4.2 Test 3 (a)(ii) BAM Fallhammer, pp. 75-82. c) 13.5.1 Test 3 (b)(i): BAM friction apparatus, pp. 104-107

Acknowledgements This work was financially supported by the joint fund of the National Natural Science Foundation of China and China Academy of Engineering Physics (NSAF, U1530101). We also thank Zaiyong Zhang (Shanghai Institute of Materia Medica) for the analysis of the crystal structures.

Author contributions $\mathrm{Xu} \mathrm{Y}$ and $\mathrm{Lu} \mathrm{M}$ designed and engineered the experiments; Xu Y performed the experiments, analyzed the data and wrote the paper with support from Wang P, Lin Q, and Du Y. Du Y contributed to the Explo5 calculation. All authors contributed to the general discussion.

Conflict of interest The authors declare that they have no conflict of interest.

Supplementary information Experimental details and supporting data are available in the online version of the paper. 


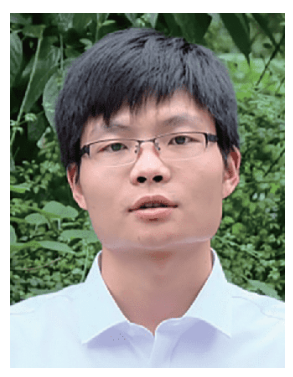

Yuangang Xu was born in Shandong (China) in 1990. He obtained his BSc degree at the North University of China in 2015 and is currently a PhD candidate of chemical engineering and technology in Nanjing University of Science and Technology (NJUST). He has published more than 10 papers. His research is focused on the synthesis of nitrogen-rich energetic materials.

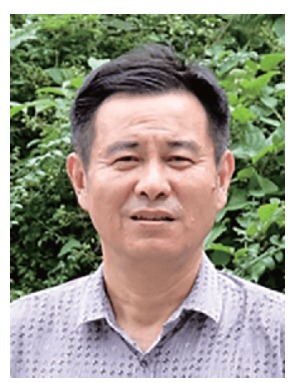

Ming Lu obtained his BSc in 1984, MSc in 1989 and PhD in 1999 at NJUST. He then became a professor in 2001. He has published more than 200 papers and 5 books, and owns more than 10 patents. His current research interest is focused on the synthesis and crystal engineering of energetic materials, pharmaceutical intermediates and green chemistry.

\section{基于一个新两性化合物的阳离子和阴离子含能材料}

许元 冈刂 $^{1}$, 王鹏程 ${ }^{1}$, 林秋汉 ${ }^{1}$, 杜耀 $^{2}$, 陆明 $^{1^{*}}$

摘要 本文报道了 $5,5^{\prime}$-二氨基-4,4' 二硝氨基-3, $3^{\prime}$-双-1,2,4-三唑(1)的第一种阳离子形式及其合成和表征. 化合物 1 与硝酸反应生成了 $\mathbf{5}$, 与 RDX相比, 这是一种具有更高的分解温度和更好爆轰性能的炸药, 与HMX相比其感度更低. 1 的阴离子作为配体和钾离子的自组装合成了 起爆药 $\mathbf{4}$, 与目前广泛使用的 $\mathrm{Pb}\left(\mathrm{N}_{3}\right)_{2}$ 相比较, 它的性能更加优异. 两性化合物 $\mathbf{1}$ 的两个衍生物的分离具有重要意义: (1) 说明了化合物 $\mathbf{1}$ 的两 性性质; (2) 开启了它们作为有前景的含能前体的研究, 为更多含能离子盐的合成提供参考. 